UDC 52-601

Doi: 10.31772/2587-6066-2019-20-2-160-165

For citation: Kornet M. E., Shishkina A. V. [Nonparametric identification of dynamic systems under normal operation]. Siberian Journal of Science and Technology. 2019, Vol. 20, No. 2, P. 160-165. Doi: 10.31772/2587-6066-201920-2-160-165

Для цитирования: Корнет М. Е., Шишкина А. В. О непараметрической идентификации динамических систем в условиях нормального функционирования // Сибирский журнал науки и технологий. 2019. Т. 20 , № 2. C. 160-165. Doi: 10.31772/2587-6066-2019-20-2-160-165

\title{
NONPARAMETRIC IDENTIFICATION OF DYNAMIC SYSTEMS UNDER NORMAL OPERATION
}

\author{
M. E. Kornet, A. V. Shishkina* \\ Siberian Federal University, Space and information technology Institute \\ 26b, Academic Kirensky St., Krasnoyarsk, 660074, Russian Federation \\ *E-mail: nastya.shishkina95@mail.ru
}

\begin{abstract}
The research gives nonparametric identification algorithms under the conditions of incomplete a priory information. The identification case differs from the previously known ones due to the fact that, besides the control action, an uncontrollable variable, but a measurable one, impacts on the object input. In contrast to parametric identification, the research considers the situation when the equations describing dynamic objects are not given with accuracy to the parameters. In this case, there are some features to study while getting the recovery characteristics of various object channels. The main characteristic is that the transition response of a channel is taken when the other channel is in a stable position. Moreover, the identification problem is analyzed under normal object operation, opposite to the previously known nonparametric approach based on Heaviside function input to the object and further Duhamel integral application. An arbitrary signal is input to the object during normal operation as a result we have a corresponding response of the object output. It should be noted that the measurements of the input and output variables are carried out with random noise. As a result, we have a sample of input-output variables. As linear dynamical system can be described by the Duhamel integral, with known input and output object variables, corresponding values of the weight function can be found. This is achieved by discrete representation of the latter. Having such realization, nonparametric estimate of the weight function in the form of the nonparametric Nadaraya-Watson estimate is used later. Substituting this with the Duhamel integral, we obtain a nonparametric model of a linear dynamical system of unknown order.

The article also describes the case of constructing nonparametric model when a delta-shaped function is input to the object. It is interesting to find out how delta-shaped function might differ from the delta function. The weight function is determined in the class of nonparametric Nadaraya-Watson estimates. Previously proposed nonparametric algorithms consider the case when Heaviside function is applied to the object; this narrows the scope of nonparametric identification practical use. It is important to construct nonparametric model of the dynamic object under conditions of normal operation.
\end{abstract}

Keywords: Duhamel integral, transient function, weight function, delta-shaped input, Nadarya-Watson estimate, nonparametric model.

\section{О НЕПАРАМЕТРИЧЕСКОЙ ИДЕНТИФИКАЦИИ ДИНАМИЧЕСКИХ СИСТЕМ В УСЛОВИЯХ НОРМАЛЬНОГО ФУНКЦИОНИРОВАНИЯ}

\author{
М. Е. Корнет, А. В. Шишкина
}

Сибирский федеральный университет, Институт космических и информационных технологий Российская Федерация, 660074, г. Красноярск, ул. Академика Киренского, $26 б$

*E-mail: nastya.shishkina95@mail.ru

\footnotetext{
Приводятся непараметрические алгоритмы идентификащии в условиях неполной информации. Существенное отличие самой задачи идентификации от известных предыдущчих задач состоит в том, что на вход объекта, кроме управляющего воздействия, действует неуправляемая переменная, но контролируемая. В отличие от параметрической идентификаџии, рассматривается ситуация, когда уравнения, описывающие динамические объекты, не заданы с точностью до параметров. В этом случае появляются некоторые особенности, которые необходимо учитывать при снятии переходных характеристик объектов по различным каналам. Основная особенность состоит в том, что переходная характеристика по одному каналу снимается при стабильном положении другого канала. Более того, задача идентификации рассматривается в условиях нормаль-
} 
ного функционирования объекта в отличие от ранее известного подхода к непараметрической идентификаичи, основанного на подаче на вход объекта функиии Хевисайда и дальнейтем применении интеграла Дюамеля. В условиях нормального функиионирования на вход объекта подают сигнал произвольной формьл. При этом на выходе объекта наблюдается соответствующий отклик. Измерения входной и выходной переменных осуществляются со случайными помехами. В итоге имеем реализацию (выборку) входных-выходных переменных. Поскольку линейная динамическая система может быть описана интегралом Дюамеля, то при известных входных и выходных переменных объекта могут быть найдены соответствуюшие значения весовой функиии. Это достигается при дискретной записи последнего. Располагая подобной реализацией, в дальнейшем используется непараметрическая оценка весовой функции в виде непараметрической оценки Надарая - Ватсона. Подставляя ее в интеграл Дюамеля, получаем тем самым непараметрическую модель линейной динамической системы неизвестного порядка.

В статье приведен так же любопытный случай построения непараметрической модели при подаче на вход дельтаобразной функции. Было интересно выяснить, насколько дельтаобразная функция может отличаться от дельта-функции. Оиенка весовой функции и в этом случае определялась в классе непараметрических оценок Надарая - Ватсона. Ранее были предложены непараметрические алгоритмы идентификации для случая, когда на вход объекта подавалась функиия Хевисайда. Это несколько сужает рамки практического использования самой идеи непараметрической идентификаџии. Естественно, важным является случай построения непараметрической модели динамического объекта, находящегося в условиях нормальной эксплуатации. Эта особенность является наиболее важной из рассматриваемых приемов идентификаиии в условиях непараметрической неопределенности.

Ключевые слова: интеграл Дюамеля, переходная функиия, весовая функиия, дельтаобразное входное воздействие, оченка Надарая - Ватсона, непараметрическая модель.

Introduction. The main objective of identification theory is the model construction based on input and output process variables observations while data about the object is incomplete [1-3]. The article considers dynamic object identification under nonparametric uncertainty [4; 5], when the dynamical model cannot be identified up to parameter vector due to the lack of a priori data. In this case getting transient response and following estimation of an object weight function are reasonable. The basis of this paper is Duhamel integral use, due to the principle of superposition [6;7]. Identification algorithms of the object in normal operation conditions are described. The research analyses three methods of obtaining weight function estimation using Heaviside function [8; 9], deltashaped input and arbitrary input.

Problem formulation. We assume that an object is a dynamic system described by equation [1], $x_{t}=f\left(u_{t}, \mu_{t}\right)$ where $f(\cdot)$ - is unknown function; $u_{t}$ - control input variable; $\mu_{t}-$ uncontrolled, but measured variable; $x_{t}$ output variable.

Fig. 1 illustrates a block diagram of the dynamic process $[1 ; 10]$, with the following notations: $\hat{x}_{t}-$ output of model; $u_{t}$ - control variable; $\mu_{t}$ - uncontrolled, but measured variable; $(t)$ - continuous time; $t$ - discrete time; $\xi_{t}, h_{t}$ - random noise influencing the object and output variable measuring channel, with zero mathematical expectation and limited dispersion.

Variables control is carried out at time interval $\Delta t$. Thus, it is possible to obtain initial input - output variable sample $\left\{x_{i}, u_{i}, \mu_{i}, i=\overline{1, s}\right\}$, where $s-$ a sample size.

Non-parametric identification algorithm when standard signals can be input to the object. We could assume that the object is described by a linear differential equation of unknown order. In this case, for zero initial conditions, $x(t)$ is found as where

$$
\begin{gathered}
x(t)=x_{u}(t)+x_{\mu}(t), \\
x_{u}(t)=\int_{0}^{t} h_{u}(t-\tau) u(\tau) d \tau, \\
x_{\mu}(t)=\int_{0}^{t} h_{\mu}(t-\tau) \mu(\tau) d \tau .
\end{gathered}
$$

Where $h_{u}(t-\tau), h_{\mu}(t-\tau)$ - weight functions of $u$ and $\mu$ channels. Weight function is a derivative of the transition function $h(t)=k^{\prime}(t)$.

This problem becomes the weight function estimation, so, first, the transition function needs to be obtained.

As it is mentioned, weight function can be obtained by various means.

First case. We suppose that the object is described by linear differential equation of unknown order. Under zero initial conditions, $x(t)$ is found as (1). Transition function is an object reaction to input impact, namely as Heaviside function $u(t)=1(t)$.

$$
1(t)=\left\{\begin{array}{l}
0, u(t)<0 \\
1, u(t) \geq 0
\end{array} .\right.
$$

After obtaining transition function, to find its nonparametric estimation is required $[11 ; 12]$ :

$$
\bar{k}(t)=\frac{T}{s c_{s}} \sum_{i=0}^{s} k_{i} H\left(\frac{t-t_{i}}{c_{s}}\right),
$$

where $\bar{k}_{i}$ - transition function estimate, $k_{i}$ - transition function, $t_{i}$ - discrete time of measurements, $s$ - sample size, $c_{s}$ - kernel smoothing, $H$ - kernel function, $T$ - time observation period [2]. 


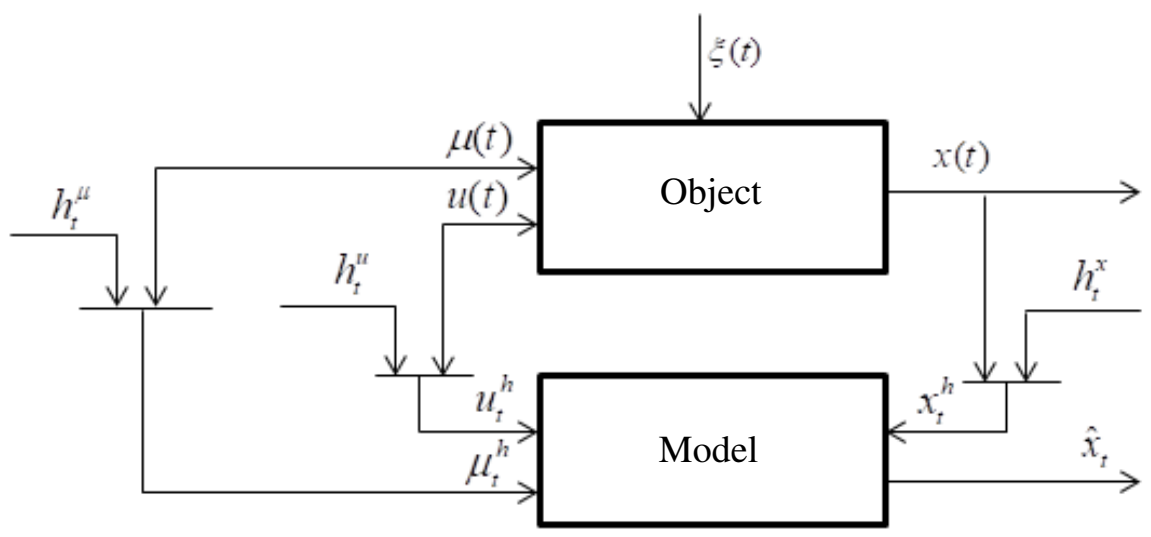

Fig. 1. Identification scheme

Рис. 1. Схема идентификации

We note that kernel function and kernel smoothing satisfy following terms $[11 ; 12]$ :

$$
\begin{gathered}
\frac{1}{c_{s}} \int_{-\infty}^{\infty} H\left(\frac{t-t_{i}}{c_{s}}\right) d t=1, \quad \lim _{s \rightarrow 0} \frac{1}{c_{s}} \int_{-\infty}^{\infty} \phi(t) H\left(\frac{t-t_{i}}{c_{s}}\right) d t=\phi\left(t_{i}\right), \\
H\left(\frac{t-t_{i}}{c_{s}}\right) \geq 0, \quad c_{s}>0, \quad \lim _{c_{s} \rightarrow \infty} s c_{s} \rightarrow \infty, \quad \lim _{s \rightarrow \infty} c_{s} \rightarrow 0,
\end{gathered}
$$

where $\phi\left(t_{i}\right)$ - an arbitrary function.

In particular, kernel function would be considered as Sobolev function (5):

$$
H=\left\{\begin{array}{l}
0,\left|t-t_{i}\right|>c_{s} \\
\frac{0.827}{c_{s}} e^{\left(\frac{-\left(t-t_{i}\right)^{2}}{\left(t-t_{i}\right)^{2}-c_{s}^{2}}\right)}, \quad\left|t-t_{i}\right| \leq c_{s} .
\end{array}\right.
$$

Since weight function $h(t)$ is derivative of transition function $k(t)$, then

$$
\bar{h}(t)=\frac{T}{s c_{s}} \sum_{i=0}^{s} \bar{k}_{i} H^{\prime}\left(\frac{t-t_{i}}{c_{s}}\right),
$$

where $\bar{k}_{i}$ - transition function estimation, $k_{i}-$ transition function, $t_{i}$ - discrete time of measurements, $s$ - sample size, $c_{s}$ - kernel smoothing, $H$ - kernel function, $T$ - time observation period.

Second case. The weight function could be obtained when a delta-shaped function is input, shown in fig. 2 . It has got step function type (7), $\Delta t$ - discretization interval

$$
\delta^{\Delta}(t)=\left\{\frac{1}{\Delta t}, t \in \Delta t,\right.
$$

where $\Delta t$, for example, is an equation $\Delta t=t^{\prime}-t^{\prime \prime}$.

Identification algorithm under normal object operation. Constructing an adaptive object model often requires identification of measuring channels under normal object operation $[2 ; 8 ; 13]$

Therefore, the third case has got the priority in solving the problem of nonparametric identification $[4 ; 6]$. The following algorithm when input impact has got sinusoidal type function (as an example) is analyzed below.

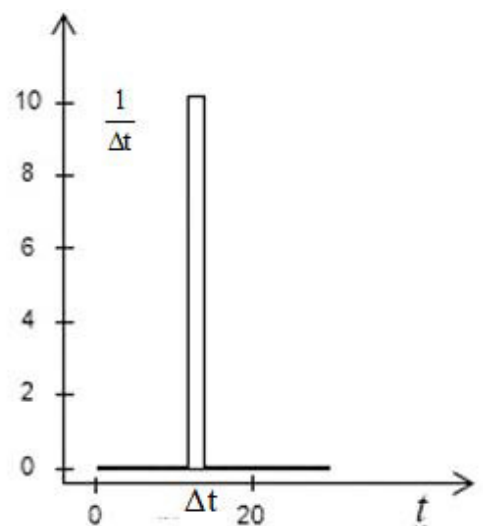

Fig. 2. Delta-shaped function example

Рис. 2. Пример дельтаобразного входного воздействия

Third case. If control action and object output are known, weight function may be described by (1).

In a discrete form:

$$
\begin{gathered}
h_{i}=\left(x_{t}^{u}-\left(\sum_{i=1}^{s} u_{i} \Delta \tau+\sum_{i=1}^{s} h_{0}\right)\right)+ \\
+\left(x_{t}^{\mu}-\left(\sum_{i=1}^{s} \mu_{i} \Delta \tau+\sum_{i=1}^{s} h_{0}\right)\right), \quad i=\overline{1, s},
\end{gathered}
$$

where $s$ - sample size; $\Delta \tau$ - variables control time interval; $u_{i}$ - control variable; $\mu_{t}$ - uncontrolled, but measured variable; $x_{t}$ - object output; $h_{0}$ - value of the weight function on previous iteration steps.

Therefore, nonparametric process model is:

$x_{s}(t)=\frac{T}{s c_{s}}\left(\int_{0}^{t} \sum_{i=1}^{s} k_{i} H^{\prime}\left(\frac{t-t_{i}}{c_{s}}\right) \mu(\tau) d \tau+\int_{0}^{t} \sum_{i=1}^{s} k_{i} H^{\prime}\left(\frac{t-t_{i}}{c_{s}}\right) \mu(\tau) d \tau\right)$ or

$$
x_{s}(t)=\frac{T}{s c_{s}}\left(\int_{0}^{t} \sum_{i=1}^{s} h_{i}^{u} u(\tau) d \tau+\int_{0}^{t} \sum_{i=1}^{s} h_{i}^{\mu} \mu(\tau) d \tau\right),
$$

where $k_{i}$ - transition function, $h_{i}$ - weight function, $c_{s}-$ kernel smoothing, $s$ - sample size, $T$ - observation period. 
Computer experiment. We suggest that dynamical an object is described by a second-order differential equation. It can be represented as:

$$
\begin{gathered}
x_{t}=x_{t}^{u}+x_{t}^{\mu}, \\
x_{t}^{u}=0.25 x_{t-1}^{u}-0.33 x_{t-2}^{u}+0.33 u_{t}, \\
x_{t}^{\mu}=0.25 x_{t-1}^{\mu}-0.33 x_{t-2}^{\mu}+0.33 u_{t} .
\end{gathered}
$$

We could suppose that the equation (10) is used to obtain sampling points. Nonparametric algorithm does not mean the known form of the differential equation, only information on the linearity of an object is known, in contrast with $[14 ; 15]$. It should be noted once again that certain equations accepted in this computational experiment remain unknown. Only a priori information about its linearity is known as well as the presence of the principle of a super position. It is important, that taking the transient characteristics for each object channel occurs when the other channel stabilizes $[16 ; 17]$.

As an arbitrary input signal in the conditions of normal operation of the object, we give a sinusoidal input action $u(t)$, it is not a controlling action, but a measured one $\mu(t)$ :

$$
\begin{aligned}
& u_{t}=\sin (0.1 t) \\
& \mu_{t}=\sin (0.05 t)
\end{aligned} .
$$

Fig. 3 uses following notations: $u(t)$ - sinusoidal input action, $\mu(t)$ - uncontrolling, but a measured variable.

We could add a random noise $h$, that arising in the channel of output signal $x(t)$ measurement

$$
h_{t}=l x_{t} \xi_{t},
$$

where $\xi_{t} \in[-1 ; 1]$, noise level $l=10 \%$.

We calculate a recovery error $-w$ according to the

$$
w=\frac{\sum_{i=1}^{s}\left|x_{t}-\hat{x}_{t}\right|}{\sum_{i=1}^{s}\left|x_{t}-\bar{x}\right|},
$$

where $\bar{x}=\frac{1}{s} \sum_{i=1}^{s} x_{t}-$ arithmetic mean, $x_{s}(t)$ - model output.

Implementing the algorithm (1), we construct a model of the object, shown in fig. 4.

Fig. 4 uses the following notations: $x(t)$ - object output; $\hat{x}(t)-$ model output; noise level $l=0 \%$; recovery error $w-0.047$, according to the chart and recovery error, this model could be considered as satisfactory.

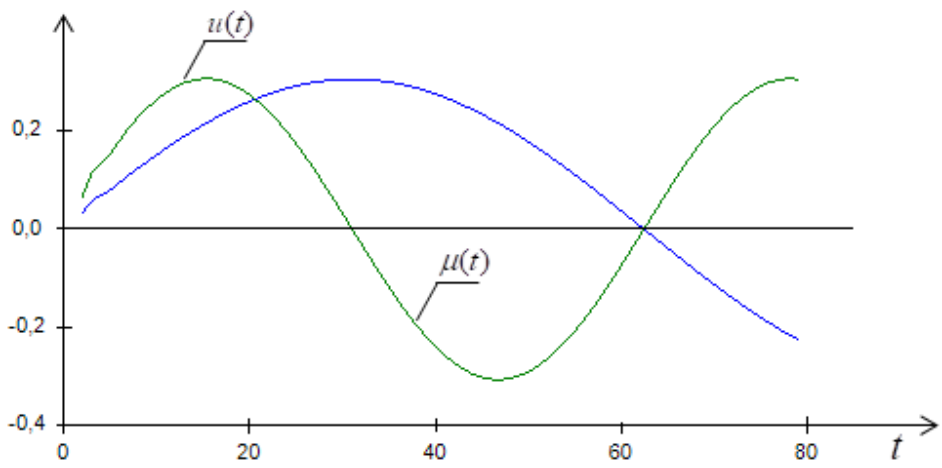

Fig. 3. Arbitrary input actions $u$ and $\mu$

Рис. 3. Произвольные входные воздействия и и $\mu$

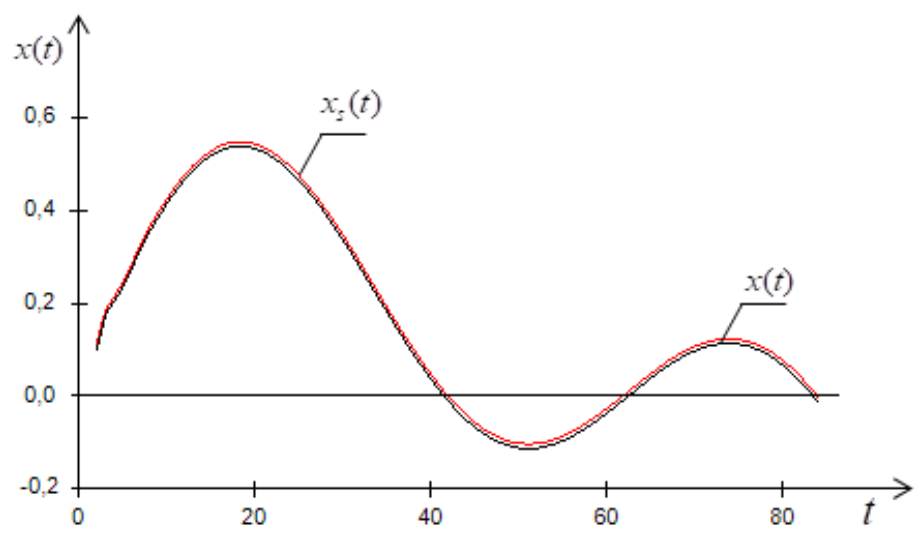

Fig. 4. Object output $x(t)$ when the input is an arbitrary sinusoidal signal

Рис. 4. Реакция выхода объекта $x(t)$ и модели, при синусоидальном входном воздействии 


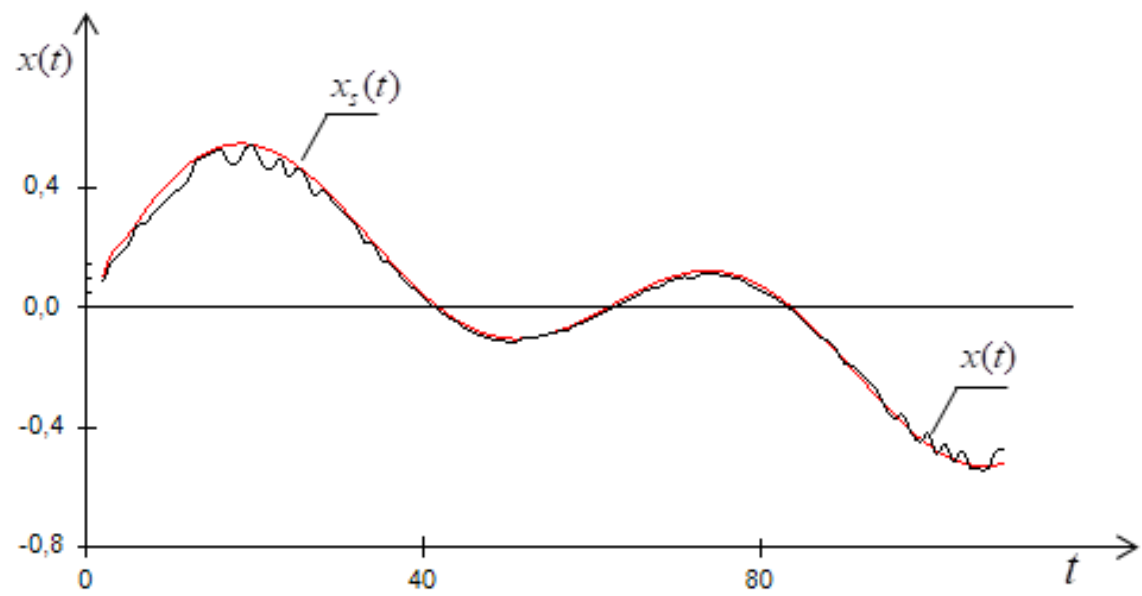

Fig. 5. Object output when the input is an arbitrary sinusoidal signal and noise level $10 \%$

Рис. 5. Результаты выхода объекта, при синусоидальном входном воздействии при уровне помех равном $10 \%$

The case when $l=10 \%$ and recovery error $w-0.112$ is shown on fig. 5 .

Conclusion. The research analyzes the problem of nonparametric identification of linear dynamical objects under the conditions of incomplete data. The main result of this paper is resolution of identification problem in an object normal operation conditions. The paper submits nonparametric linear dynamical system models based on Duhamel integral estimation by means of NadarayaWatson statistics.

The main conclusions based on the extensive numerical research of nonparametric models are following: although in practice delta function cannot be submitted to the object input, sometimes it is possible to submit delta-shaped input signal and then construct a satisfactory model. Undoubtedly, noise increase in input-output variables measurement and increase in discreteness of input-output variables control deteriorate an accuracy of nonparametric models.

In addition, it is important to note that a researcher does not know a particular object equation and a differential equation order; moreover, all equations described are analyzed as examples. Therefore, algorithm does not depend on the type of input impact, the main condition is observance of the superposition principle.

\section{References}

1. Tsypkin Ya. Z. Informatsionnaya teoriya identifikatsii [Information theory of identification]. Moscow, Nauka, Fizmatlit Pabl., 1995, 336 p.

2. Raibman N. N. Chto takoe identifikatsiya [What is identification]. Moscow, Nauka Pabl., 1970, 119 p.

3. Eykhoff P. Osnovy identifikatsii sistem upravleniya [Fundamentals of identification of control systems]. Moscow, Mir Publ., 1975, 681 p.

4. Medvedev A. V. Neparametricheskie sistemy adaptatsii [Nonparametric adaptation systems]. Novosibirsk, Nauka Publ., 1983, 174 p.

5. Medvedev A. V. [Adaptation under conditions of non-parametric uncertainty]. Adaptivnye sistemy $i$ ikh prilozheniya [Adaptive systems and their applications]. Novosibirsk, Nauka Publ., 1978, P. 4-34.

6. Medvedev A. V. [The theory of nonparametric systems. Modeling]. Vestnik SibGAU. 2010, No. 4 (30), P. 4-9 (In Russ.).

7. Medvedev A. V. [Elements of the theory of nonparametric control systems]. Aktual'nye problemy informatiki, prikladnoy matematiki $i$ mekhaniki. Informatika [Actual problems of computer science, applied mathematics and mechanics. Information technologies]. Novosibirsk, Krasnoyarsk, Izd-vo Sib. otd-niya Ros. akad. Nauk Publ., 1996, P. 87-112.

8. Metody klassicheskoy $i$ sovremennoy teorii avtomaticheskogo upravleniya. T. 1: Matematicheskie modeli, dinamicheskie kharakteristiki $i$ analiz sistem upravleniya [Methods of classical and modern theory of automatic control. Vol. 1. Mathematical models, dynamic characteristics and analysis of control systems]. Ed. K. A. Pupkova, N. D. Egupova. Moscow, MSTU named after N.E. Bauman Publ., 2004, 656 p.

9. Metody klassicheskoy $i$ sovremennoy teorii avtomaticheskogo upravleniya. T. 2: Statisticheskaya dinamika i identifikatsiya sistem avtomaticheskogo upravleniya [Methods of classical and modern theory of automatic control. Vol. 2. Statistical dynamics and identification of automatic control systems]. Ed. K. A. Pupkova, N. D. Egupova. Moscow, MSTU named after N. E. Bauman Publ., 2004, 640 p.

10. Shishkina A. V., Agafonov E. D., Shishkina A. V. [Nonparametric control of a dynamical system]. Siberian Journal of Science and Technology. 2018. Vol. 19, No. 4, P. 711-718 (In Russ.).

11. Nadaraya E. A. Neparametricheskoe otsenivanie plotnosti veroyatnostey $i$ krivoy regressii [Nonparametric estimation of the probability density and the regression curve]. Tbilisi, Izd. Tbil. University Publ., 1983.

12. Kotkinik V. Ya. Neparametricheskaya identifikatsiya i sglazhivanie dannykh [Nonparametric identification and data smoothing]. Moscow, Nauka Publ., 1985, $336 \mathrm{p}$. 
13. Grop D. Metody identifikatsii system [Methods of identification of systems]. Moscow, Mir Publ., 1979, $304 \mathrm{p}$.

14. Tse E., Bar-Shalom Y. An actively adaptive control for linear systems with random parameters via the dual control. Automatic Control. IEEE Transactions. 2003, Vol. 18, Is. 2, P. 109-117.

15. Wenk C. J. Bar-Shalom, Y. A multiple model of an adaptive dual control algorithm for stochastic systems with unknown parameters Automatic Control. IEEE Transactions. 2003, Vol. 25, Is. 4, P. 703-710.

16. Liung L. Identifikatsiya sistem [Identification of systems]. Moscow, Nauka Pudl., 1991, 423 p.

17. Metody klassicheskoy $i$ sovremennoy teorii avtomaticheskogo upravleniya. T. 3: Sintez regulyatorov sistem avtomaticheskogo upravleniya [Methods of classical and modern theory of automatic control. Vol. 3. Synthesis of regulators of automatic control systems]. Ed. K. A. Pupkova, N. D. Egupova. Moscow, MSTU named after N. E. Bauman Publ., 2004, 656 p.

\section{Библиографический список}

1. Цыпкин Я. 3. Информационная теория идентификации. М. : Наука ; Физматлит, 1995. 336 с.

2. Райбман Н. С. Что такое идентификация. М. : Наука, 1970. 119 с.

3. Эйкхофф П. Основы идентификации систем управления. М. : Мир, 1975. 681 с.

4. Медведев А. В. Непараметрические системы адаптации. Новосибирск : Наука, 1983. 174 с.

5. Медведев А. В. Адаптация в условиях непараметрической неопределенности // Адаптивные системы и их приложения. Новосибирск : Наука ; СО АНССР, 1978. C. 4-34.

6. Медведев А. В. Теория непараметрических систем. Моделирование // Вестник СибГАУ. 2010. № 4 (30). С. 4-9.

7. Медведев А. В. Элементы теории непараметрических систем управления // Актуальные проблемы информатики, прикладной математики и механики.
Информатика. Новосибирск ; Красноярск : Изд-во Сиб. отд-ния РАН, 1996. С. 87-112.

8. Методы классической и современной теории автоматического управления. Т. 1: Математические модели, динамические характеристики и анализ систем управления / под ред. К. А. Пупкова, Н. Д. Егупова. М. : МГТУ им. Н. Э. Баумана, 2004. 656 с.

9. Методы классической и современной теории автоматического управления. Т. 2: Статистическая динамика и идентификация систем автоматического управления / под ред. К. А. Пупкова, Н. Д. Егупова. М. : МГТУ им. Н. Э. Баумана, 2004. 640 с.

10. Шишкина А. В., Агафонов Е. Д., Шишкина А. В. О непараметрическом управлении динамической системой // Сибирский журнал науки и технологий. 2018. T. 19, № 4. С. 711-718.

11. Надарая Э. А. Непараметрическое оценивание плотности вероятностей и кривой регрессии. Тбилиси : Изд-во Тбил. ун-та. 1983.

12. Катковник В. Я. Непараметрическая идентификация и сглаживание данных. М. : Наука, 1985. 336 с.

13. Гроп Д. Методы идентификации систем : пер. с англ. М. : Мир , 1979. 304 с.

14. Tse E., Bar-Shalom Y. An actively adaptive control for linear systems with random parameters via the dual control approach Automatic Control // IEEE Trans. 2003. Vol. 18, Is. 2. P. 109-117.

15. Wenk C. J. Bar-Shalom, Y. A multiple model adaptive dual control algorithm for stochastic systems with unknown parameters Automatic Control // IEEE Trans. 2003. Vol. 25, Is. 4. P. 703-710.

16. Льюнг Л. Идентификация систем. М. : Наука, 1991. $423 \mathrm{p}$.

17. Методы классической и современной теории автоматического управления. Т. 3. Синтез регуляторов систем автоматического управления / под ред. К. А. Пупкова, Н. Д. Егупова. М. : МГТУ им. Н. Э. Баумана, 2004. $656 \mathrm{c.}$

(C) Kornet M. E., Shishkina A. V., 2019

Kornet Maria Evgenievna - applicant of the Department of System Analysis and Operations Research; Reshetnev Siberian State University of Science and Technology, Institute of Informatics and Telecommunications. E-mail: marya.kornet@gmail.com.

Shishkina Anastasia Vasilyevna - graduate student; Siberian Federal University, Institute of space and information technologies. E-mail: nastya.shishkina9666@mail.ru.

Корнет Мария Евгеньевна - соискатель кафедры системного анализа и исследования операций; Сибирский государственный университет науки и технологий имени академика М. Ф. Решетнева, Институт информатики и телекоммуникаций. E-mail: marya.kornet@gmail.com.

Шишкина Анастасия Васильевна - магастрант; Сибирский федеральный университет, Институт космических и информационных технологий. E-mail: nastya.shishkina9666@mail.ru. 